\title{
Philosophical analysis of models of engineering education in Russia
}

\author{
V. N. Fadeeva ${ }^{1}$, M. A. Makienko ${ }^{1}$, E.G. Avanesova ${ }^{2}$ \\ ${ }^{1}$ Tomsk Polytechnic University, 634050 Lenin Avenue, 30, Tomsk, Russia \\ ${ }^{2}$ Tomsk State University, 634050 Lenin Avenue, 36, Tomsk, Russia
}

\begin{abstract}
This article defines the principles of the philosophical approach to the problems of engineering education. Ontological, epistemological and axiological components of the proposed approach are distinguished. Assessment criteria of engineering education models are specified. Basing on the presented principles and criteria, the analysis of Russian engineering education models is performed. The authors distinguish the following models: classical (tsarism), soviet transitional, soviet industrial, physicotechnical model, soviet mass (reproductive) and Russian transitional models. In addition among developing models it is possible to recognize the following ones: methodological (creative) and outrunning (advanced) models. On the basis of the performed analysis, positive and negative aspects of the distinguished models are determined, and, it is possible to make a conclusion that every accomplished model emergence was reasoned by particular issues raised in the state at the particular period of time. The talking point of the necessity to design a proactive model of engineering education is formulated.
\end{abstract}

\section{Introduction}

Philosophical analysis allows seeing the phenomenon integrally and basing on application of systemic and historical methods, which involves the study of the object by means of problematization of ontological, epistemological and axiological aspects. On the basis of the proposed approach, analysis criteria are formulated.

\section{Materials and methods}

The axiological aspect manifests itself in the analysis of the purposes and objectives of engineering education. During this analysis the purpose of engineer training is determined, along with the scope of her/his activity in compliance with practical needs of state, society and business activity. For the analysis engineering education system, the ontological aspect should include a description of the elements composing the training process of engineers e.g. the organizational university structure and the education management principles.

The participants of the educational process are determined as to whom and who. To whom: qualitative and quantitative characteristics of enrollees; public image of the engineering profession, the student concernment in the future profession, and the image of the engineer. Who: the quality of the teaching staff involved in the training of future engineers, personal and professional characteristics.

\footnotetext{
a Corresponding author: nikavera791@gmail.com
}

The epistemological aspect renders it possible to analyze the issues of methodology, didactics and the contents of the educational process. What: training curriculum, the proportion of special subjects, natural and human science academic disciplines, the level of language training. How: the methodology of training, the practical skills theory supplement, participation in the production process.

\section{Results and discussion}

The engineering education model can be designed on the basis of the analysis of pre-existing, existing or anticipated systems of engineering education. This article chronologically presents a brief analysis of the Russian engineering education systems in the context of the historical, political and economic situation in the country. While performing the analysis the authors relied on the experience of the Tomsk Polytechnic University.

1. The classical (tsarism) model. Purpose. Training of engineers was associated with the challenges which the country was facing. For example, by the order of Peter the $1^{\text {st }}$, the School of Mathematics and Navigation was established in Moscow in 1701; in 1773 the Mining Institute of the Empress Catherine II was founded in St. Petersburg, etc. Tomsk Technological Institute (TTI) was also founded according to development needs of Siberia. 
To whom. The dynastic nature of the classical model: engineering became a family profession. However, the Tomsk Technological Institute was created as one of the first higher education institutions in Siberia and the dynastic nature was not relevant for Tomsk. Certain enrollment restrictions were distinguished. According to the statutes of the TTI, Russians enrollees took priority over the foreigners, as well as ones of the Asian part of Russia. [1]. Also the process of enrollment was based on the gender principle; due to this reason only male persons were enrolled. The enrollment of priesthood representatives was also put under the ban. The established statutory rate for applicants professing Judaism was only $5 \%$ [1].

There was a high competition among applicants for a privilege to obtain a state-funded place. But at the same time the cost of education was reasonable, in comparison with the world level. To maintain order at the university, the so-called disciplinary court was invented. Education played a role of a "social lift". For example, in 1902 the social structure of the students of the TTI was democratic; the students qualified as engineers were granted with the status of honorable citizens irrespective of their origin.

Who. The high salary and high status of teaching stuff attracted the best specialists. A professor could receive a full retirement pay after 25 years of work. A professor, who had worked as a teacher for 25 years, was given the title of Distinguished Professor of the Institute and the opportunity to keep his full retirement pay despite the salary drawn working out of the institute.

What and how. Within the context of the classical engineering education model, training of not only a specialist but a person in general was expected, so the emphasis was on teaching the basic engineering disciplines and the disciplines of spiritual or humanitarian sphere, which contributed to personality formation. In addition, one of the professional competencies of an engineer in Tsarist Russia was leadership ability, which was developed through the military and patriotic education. Apart from it in Tomsk Technical Institute such special subjects, as advanced mathematics, construction and mining jurisprudence, theology, political economy, statistics, accounting and foreign languages were taught.

The Methodology of teaching included the following tasks: theory complementation with practical skills, insurance of students in production process participation. Integration of physics and mathematics methods, as well as their inclusion in the process of applied problems solution took place; this trend has formed a so-called physicotechnical system.

The determination of engineering education model of the Soviet period is a very controversial question. For the purposes of discussion, the authors propose to divide the history of Soviet Union engineering education into several stages.

2. The soviet transitional model of engineering education. The stage of formation of the Soviet engineering education was characterized by succession on the one hand and, and by break of the prerevolutionary system, on the other hand. The development of technical universities passed in two directions: the higher educational institutions, which remained from the Tsarist Russia, were retained and the new ones were established.

At the time the Soviet regime establishment, purposes and objectives of the engineer were determined by the need of destroyed economy recovery and formation of the future communist society economic base. In 1920, the resolutions on electrification and on heavy industry were adopted; they determined the further development strategy. One of the most important tasks was mobilization of those who had sufficient qualification for teaching the production and electricity academic disciplines. [2].

To whom. Universities enrollment was carried out taking into account the class position, preference was given to students with worker's and peasant's origin; all applicants over the age of 16 were enrolled irrespective of nationality and gender without a school leaving certificates or diplomas, tuition cost was also abolished [3]. By all means this affected the quality of enrollees' knowledge. Many students could not adequately receive knowledge, due to the fact that "insufficient financial security of students distracted them from their studies" [4]. For example, V.I. Kominov, who graduated from the TTI in 1934, wrote: "The teaching stuff was still partially represented by people of prerevolutionary high school, they were critical towards the young people, with workers' and peasants' origin, and did not really believe that these students were able to reach the pinnacles of science and technology" [5]. The secondary school of the 20s of XX did not provide the proper education and knowledge necessary for studying in a higher education institution. This problem was solved by establishing the worker's faculties. The students were also encouraged by the educational maintenance allowance comparable with the average salary.

Who. The system of teachers' differentiation, which existed under tsarist rule, was also abolished; the professorship vacancy filling competition on the national level was conducted. The revolution resulted in the emigration of many specialists and teachers. To solve this problem, postgraduate training programs were established; production experts were involved in teaching; great importance was attached to the salary level and to the social status of teachers.

What and how. The changes also affected the principles of the university management, significantly reducing the academic freedom of its employees, determining not only the principles of management, but also the principles of the educational process and the content of training courses. The trends characterizing the technical academic institution development of that time can be traced by the example of the TTI. These trends were: rescheduling of training terms and their reduction in order to accelerate specialists training process; the revision of curricula; the transition to focused specialization, which seemed more efficient for accelerated graduation. The focus on accelerated training brought up the issue of closer connection with the production in order to introduce future engineers to the problems and peculiarities of the production process in 
advance. Specialists were trained for work in certain industries, and educational institutions were classified according to manufacturing industries peculiarities, enabling engineers to get acquainted with their tasks immediately and solve the problems of practice. The engineer was also brought up from the viewpoint of ideology: a person was not just an engineer, he was a builder of communism as well [4].

3. The soviet classic (industrial) model of engineering education. Purpose. In the late 20 s the Soviet government developed a national industrialization plan, which required preparation of a great number of engineers of several profiles: firstly, engineers capable to managing the production process at various levels, and secondly, engineers capable to invent new devices on the basis of science and technology achievements. During the period of the first 5-year industrial plan implementation (since 1928 to 1933) the development of large-scale automotive, chemical, processing and aviation factories as well as railways was facilitated. These factors required to readjust the approach to engineering education.

To whom. All citizens between 17 and 35 years who had school leaving certificate and successfully passed the entrance exams in a certain university had the right of enrollment and free education.

Who. The teaching stuff was recruited from university graduates.

What and how. There were the following teacher assisted forms of training activities: lectures given by professors or associate professors; practical training under the guidance of professors, associate professors or assistants; work experience internship. The student performance criteria were the examination of the course of lectures and practical training credit tests. In educational system of that there was a return to the state examinations practice, as well as to defense of a graduation practice thesis submitted to approval of State Examination Commission in technical universities.

4. The physicotechnical model system. The recovery of the state after the Great Patriotic War required special conditions for engineers training, capable to implement quickly and efficiently new largescale projects. Such conditions were provided as a part of a physicotechnical model, which provided for the training of engineers, research engineers, designers, managers of industrial laboratories and research institutes.

Purpose. Both scientists and factory managers were aware of the need for a new approach to engineering education; thus, the initiative group put forward the idea of establishing a new educational institution. In 1946, on February the 1st, P.L. Kapitsa addressed a letter to I. Stalin, in which he pointed out the shortcomings of the existing system of engineering education and formulated the "Physicotechnical system principles". The principles consisted in careful selection of applicants, prone to innovative thinking; leading researchers participation in training and favorable working environment creation; an individual approach to certain students in order to develop their creative abilities; initial training in technological research context and functional creation with the help of the core national laboratories; 4 year period of university study along with 2 year period of practice in leading research institutes and design bureaus. [6].

To whom. The physicotechnical model suggested strict selection of enrollees. The first stage was performed as the usual set of admission tests; the second stage included the tests in mathematics and physics, which required intelligence rather than new knowledge. Examination commissions responsible for new students' enrollment were created in different regions of the country [7]. The basic principle underlying in the physicotechnical system is that a student, first of all, is a person who learns but not a person who is taught.

Who. Theoretically, teachers should not work on a permanent basis; everyone had to combine scientific and practical activities with teaching. But it was impossible to implement this idea completely. However, a substantial number of teachers were globally renowned researchers with high salaries.

What and how. Attendance was voluntary, but the lectures on the fundamental courses, represented by distinguished scholars, defined the teaching process peculiarities themselves. Fundamental subjects were studied for 3 years according to the general plan, regardless of the qualification. The system included training for specific areas, therefore scientific seminars were held on their basis; their purpose was to plunge students into their future occupation. Lectures on human sciences, with the exception of foreign languages courses, were given in a condensed form. Learning foreign languages students were able to read foreign literature in the original [4].

5. The soviet mass (reproductive) model of engineering education. The purposes and objectives of engineers training remained the same, but priorities were set differently. The engineer had to reproduce available experience.

To whom. Training of engineers became more extensive, and as a result, the selection criteria became less strict. Engineering professions became not prestigious and low-paid. Since the $80-\mathrm{s}$, the ratio of engineers to the overall number of students began to decline.

Who: The Soviet model was characterized by close association with enterprises; representatives of various plants and factories were members of professorate. At the same time, there was an obvious lack of teachers with academic degree in the institutes; teachers were overwhelmed with teaching and social work due to the increasing number of students. The living conditions of teachers were far from perfect. At the same time, the outflow of teaching staff to blue-collar jobs was repeatedly observed.

What and how. Engineers training requirements were reduced. Despite the active measures taken by the Government to finance the higher education institutions, the lack of the necessary materials or equipment for carrying out the necessary research was observed from time to time.

6. The Russian transitional model. Purpose. The so called "Perestroika" (restructuring) influenced the 
system of engineering education. Primarily resource economy resulted in the manufacturing sector reduction, which in its turn led to reduction in demand for engineers.

To whom. There was a trend of applicants' poor preparation, associated with a systemic crisis in education and low social status of teachers. Engineering professions were not prestigious anymore. The share of female students increased; the problem was that they studied at the university to get a diploma of higher education but not a qualification as a result they were not going to work within their specialty.

Who. The market system affected the system of higher education institutions as well. Teachers had to make money and the most ambitious and entrepreneurially-inclined ones left their profession. Engineering training was replaced by professions which were in demand on the market.

What and how. The funding was reduced. One could speak of a general crisis in the education system and imbalance in the choice of professions by modern applicants. There was a constant revision of curricula and working programs.

7. The methodological (creative) model of N.P. Kirillov.

The concept of methodological model is based on the analysis of modern engineers' main areas of activity. The author refers to the work of Henry Etzkowitz "The Triple Helix: University-Industry-Government" and offers his vision of the issue, extending and specifying these areas. The paper of N.P Kirillov [8] presents them as science, industry, business and government. Basing on this classification, we propose the following professional images of the engineer: engineer-scientist, engineermanufacturer, engineer-businessman, engineergovernment (manager), engineer-teacher and engineerartist. Such vision of the modern engineer dictates the conditions of her/his shaping. According to the creative basis of engineering activities, we propose to include the following structures into the model of engineering education: management, psychology, pedagogy, methodology.

The purposes and objectives of the engineer training are defined as supplement of engineering skills to industry, science, business and government.

To whom. A new qualitative characteristic of applicants is the talent of unconventional, creative thinking, the ability to solve tasks by finding one's own way without following well-established algorithms.

Who. The quality of the teaching staff must meet the requirements of the model: the teacher should be focused on the use of active methods in the organization of the educational process and train students to think critically and develop their creativity. This means that teachers must be open for search of new methods of materials presentation, communication with students, as well as adjustment of new ideas to the educational process.

What and how. The methodology of training maintains technical focus and includes large humanitarian component, first of all designed to form critical thinking and the ability to understand the social component of engineering [9].
8. The level concept of Pokholkov Yu.P. (a model of outrunning advanced education)

Yuri P. Pokholkov, a President of the Russian Engineering Education Association, expressed the idea of advanced engineering education. Pokholkov formulates the purpose of engineering education in Russia in the following way: "It is necessary to create adaptive system of advanced training foe specialists with higher education in engineering and technology; it will provide a world-class of specialists with individual professional skills, a high level of technological receptibility of society and ensure economic, technical and technological security of the state " [10].

To whom. Achievement of the purpose is possible in case of high-quality organization of the level engineer training. The level training includes the following stages: bachelor of engineering and technology, master of engineering and technology, certified engineer. Consequently, the relevant requirements and a certain place in the structure of production and business activity are applied for each level of training.

Any person with secondary education and the desire to receive technical education can get a bachelor's degree in engineering and technology. According to the author, this level of education should be publically available, and should be financed by the government. In terms of professional competencies, the bachelor should be capable of high-quality design and operation of technical devices. It is of interest that in addition to the competencies required by the education program, he should also have a labour grade and business competencies. He can perform the duties of a technician, a process manager, a supervisor or a technical officer in a small business.

Master's degree is the basis engineering elite establishment. Master courses should be paid by the customer: the government, the student or the enterprise. Within her/his working practice, she must independently find and solve engineering problems, as well as organize production in a small and medium business.

A certified engineer (the contingent of them should not exceed $3-5 \%$ of the total number of people with higher technical education). The applicant must have postgraduate practical experience over 7 years, as well as experience of working on a major engineering project. Willingness to design and solve complex engineering problems, constant self-education and social responsibility are of great importance [11].

What and how. Achievement of this goal is possible in case of high-quality arrangement of level engineer training. The bachelor should be capable of high-quality design and operation of technical devices and have some labour grade and business competencies. Within his working practice the Master must independently find and solve engineering problems and organize production in a small and medium business.

\section{Conclusion}

On the basis of the proposed analysis of the engineering education models, it is possible to conclude that 
effectiveness of engineering education is directly correlated with the current problems which the state faces, the level of economic development and its features, the interest of the state in human resources. The problems which the state tries to solve by development or restructuring of engineering education are mainly the problems of economic development in line with global trends. According to the authors, engineering education is characterized by "overtaking nature", which responds to the existing challenge. The following problems which are solved in the process of creating an educational model are also typical: the requirements to the engineer, the knowledge which students need to master; acquisition of practical skills as early as in the learning process; courses that must be included in the curriculum. Solution of problems related to the teaching staff brings up questions of social status of the teachers, the concept of the government in terms of development of the state. The authors agree with A. Yu. Karpova, that this "an old new trend" [12] in engineering education. The appreciated models of engineering education proposed in the article correspond to the concept of the authors: education must be of a proactive nature and aimed at prevention of social problems. This means that the alumnus of an engineering high school should be aware of anthropocentricity of his profession and its focus on human and creative nature. The engineer must have an understanding of a human, her/his physiological, social and individual components, the interdependence of technology development and transformation of a society and a person. The conceptualization of a proactive model will be presented in subsequent studies of the authors.

\section{Acknowledgment}

The article is supported by the Russian Humanitarian Science Foundation grant № 16-16-70006.

\section{References}

1. Polozhenie o Tomskom Tekhnologicheskom institute Imperatora Nikolaia II. Tomsk: Parovaya tipolitografiya Publ., I.I. Makushina, (1900)

2. Ob elektrifikatsii Rossi, Postanovlenie VIII Vserossiiskogo s'"ezda sovetov rabochikh, krest'ian, krasnoarmeiskikh I kazachikh deputatov ot 20 dekabria 1920. [Historical materials] URL: http://istmat.info

3. O pravilakh priema $v$ vysshie uchebnye zavedeniia, Dekret Soveta narodnykh komissarov RSFSR ot 2 Avgusta 1918. [Historical materials] URL: http://istmat.info

4. M.A. Usov 25-letie ucheno-uchebnoi deiatel'nosti Tomskogo Tekhnologicheskogo Instituta: doklad prorektora professora M.A. Usova, Tomskii Tekhnologicheskii Institut za 25 let svoego sushchestvovaniia Tomsk. Sibirskiy tekhnologicheskiy institute Publ. (1928)

5. Istoriia Tomskogo Politekhnicheskogo Instituta v dokumentakh. (Tomsk University Publ, 1987)

6. N.V. Karlov, Shershavym iazykom prikaza. Fizteh.
Arkhivnye documenty. 1938-1952. (Moscow, Publ., 2006)

7. N.V. Karlov, N.N. Kudryavtsev, V.A. Shkol'nikov, Dve stat'i o fiztekhe (Moscow, Publ., 2002)

8. N.P. Kirillov, Yu.S. Plotnikov, Nauka. Biznes. Vlact' (Tomsk: TUSUR, Publ., 2011)

9. V.N. Fadeeva, N.P. Kirillov, Procedia - Social and Behavioral Sciences, 166, (2015)

10. Yu. P. Poholkov, Engineering Education, 12, 2012

11. The Russian certification and registration of professional engineers ATES. [Association for Engineering Education of Russia. Official Site]. URL: http://portal.tpu.ru/apec_eng

12. A.Yu. Karpova, D.A. Karpov, Yu. Yu. Kryuchkov, Tomsk State University Bulletin, 376, (2013) 